\title{
The Current Role of Anaplastology in Maxillofacial Surgery
}

\section{Pingarrón-Martín L* and Rey-Biel J}

Department of Oral and Maxillofacial Surgery, Hospital Universitario, Spain

Facial defects can result from trauma, ablative surgery for neoplastic processes or congenital malformations. Correction of such defects goes far beyond aesthetic considerations so the choice between the surgical reconstruction and prosthetic restoration of large defects remains a difficult one and depends on the size and etiology of the defect as well as on the wish and condition of the patient [1]. Reconstruction of facial defects is a difficult challenge and up to the present, on the cusp of new transplant era, surgeons must not forget the possibility of prosthodontic restoration.

Surgeons are limited by the availability of tissue, the compromised local vascular bed, the need for periodic oncological control and physical condition of the patient. When surgical reconstruction is not possible for patients with facial deformities, the choice of treatment is prosthetic rehabilitation. However, facial prosthetics are often not considered as a reconstructive option because the patient and surgeon alike are not familiar with their application [2].

Although surgery can correct the majority of defects, it may fall short of patient's expectations. It is important for the reconstructive surgeon to be able to accurately advise and explain the patient's reconstructive options both in terms of surgery and prosthetics.

These prostheses are retained with adhesives, tissue undercuts, or in some cases with extraoral osseointegrated implants. The aesthetic result depends on the amount of tissue removed, type of reconstruction, morbidity of multimodality adjunctive treatment, and the physical characteristics of the supporting tissue available to retain the prosthesis.

Facial prosthetics has expanded over time as improvement in surgical techniques and materials developed. Anaplastology is the art and science of creating artificial anatomy.

The process is relatively inexpensive, allows for periodic evaluation and cleaning of the surgical site, and is an alternative to surgery in unsuitable candidates. The fabrication process is relatively short, and unlike the surgeon, the anaplastologist has complete control of the color, shape, and position of the prosthesis. Disadvantages include possible irritation of the tissue site, the need for periodic remakes, and reliance on adhesives or some other form of retention. Furthermore, the patient may view the prosthesis as a mask and not a part of his or her body [3].
When counseling a patient as to whether surgical or prosthetic reconstruction is the best option, it is important to remember that the goals of reconstruction are to restore both form and function and a sucessful result starts when surgeon listen to the patient and thoroughly analyzes his expectations [4].

Surgeons always must try to provide our patients with the best alternative but sometimes we don't listen to what rehabilitation the patients really want to get, or we too much focused on our own technical solutions.

The three main facial features most commonly reconstructed with facial prosthetics are the nose, orbit, and ear.

The ablative surgeon should understand the different concepts in of all three locations to comprehend the need of an optimal tissue bed. Basic principles for the surgeon to remember when ablative surgery is performed are to maintain symmetry of the face, to avoid distorting adjacent facial structures when using a primary closure or flap to cover a surgical site, to create non-hair-bearing tissues where the prosthesis needs to be placed and maintain slightly mobile and healthy tissue for the defect site [5].

The success of facial prosthetic rehabilitation depends on the surgeon's commitment to following prosthodontic guidelines during the ablative and reconstructive procedures. The team approach is the best way to achieve optimal rehabilitative results.

\section{References}

1. Johnson F, Cannavina G, Brook I, Watson J (2000) Facial prosthetics: techniques used in the retention of prostheses following ablative cancer surgery or trauma and for congenital defects. Eur J Prosthodont Restor Dent 8: 5-9.

2. Wolfaardt J, Sugar A, Wilkes G (2003) Advanced technology and the future of facial prosthetics in head and neck reconstruction. Int J Oral Maxillofac Surg 32: $121-123$

3. Lemon JC, Kiat-amnuay S, Gettleman L, Martin JW, Chambers MS (2005) Facial prosthetic rehabilitation: preprosthetic surgical techniques and biomaterials. Curr Opin Otolaryngol Head Neck Surg 13: 255-262.

4. Hickey AJ, Salter M (2006) Prosthodontic and psychological factors in treating patients with congenital and craniofacial defects. J Prosthet Dent 95: 392-396.

5. Bergstrom K (1997) Anaplastological techinique for facial defects. In Branemark P-I, Oliveira MF, editors. Craniofacial prostheses: anaplastology and osseointegration. Carol Stream, Illinois: Quintessence Publishing Co, Inc 101-110.

*Corresponding author: Pingarrón-Martín L, Department of Oral and Maxillofacial Surgery, Hospital Universitario, Fundación Jiménez Díaz, Avda, Reyes Católicos, 2. 28040 Madrid, Spain, Tel: +34696580494; E-mail: Iorenapingarron@yahoo.es

Received November 16, 2013; Accepted December 06, 2013; Published December 10, 2013

Citation: Pingarrón-Martín L, Rey-Biel J (2013) The Current Role of Anaplastology in Maxillofacial Surgery. Anaplastology 3: 123. doi: 10.4172/2161-1173.1000123

Copyright: (c) 2013 Pingarrón-Martín L, et al. This is an open-access article distributed under the terms of the Creative Commons Attribution License, which permits unrestricted use, distribution, and reproduction in any medium, provided the original author and source are credited. 